\title{
Influenza Virus Infection is not Affected by Serum Amyloid P Component
}

\author{
Jeff Herbert, ${ }^{1}$ Winston L. Hutchinson, ${ }^{1}$ Jackie Carr, ${ }^{2}$ Jane Ives, $^{2}$ Roland Jakob-Roetne, ${ }^{3}$ \\ Ken-ichi Yamamura, ${ }^{4}$ Misao Suzuki, ${ }^{4}$ and Mark B. Pepys ${ }^{1}$ \\ ${ }^{1}$ Centre for Amyloidosis and Acute Phase Proteins, Department of Medicine, Royal Free \\ and University College Medical School, Royal Free Campus, London, UK \\ ${ }^{2}$ Viral Diseases, Roche Discovery Welwyn, Welwyn Garden City, Herts, UK \\ ${ }^{3}$ Chemistry Section, F Hoffmann-La Roche Ltd, Basel, Switzerland \\ ${ }^{4}$ Institute of Molecular Embryology and Genetics, and Center for Animal Resources and Development, \\ Kumamoto University, Japan
}

Accepted January 9, 2002

\begin{abstract}
Background: Binding of serum amyloid $\mathrm{P}$ component (SAP) to its ligands, including bacteria, chromatin and amyloid fibrils, protects them from degradation, is antiopsonic and anti-immunogenic. SAP thereby enhances the virulence of pathogenic bacteria to which it binds. However SAP also contributes to host resistance against bacteria to which it does not bind. Human SAP has been reported to bind to the influenza virus and inhibit viral invasion of cells in tissue culture. We therefore investigated a possible role of SAP in either host resistance or viral virulence during influenza infection in vivo.

Materials and Methods: The clinical course of mouse adapted influenza virus infection, the host antibody response, and viral replication, were compared in wild type mice, mice with targeted deletion of the SAP gene, and mice transgenic for human SAP. The effects of reconstitution of SAP deficient mice with pure human SAP, and of a
\end{abstract}

drug that specifically blocks SAP binding in vivo, were also studied. Binding of mouse and human SAP to immobilized influenza virus was compared.

Results: The presence, absence, or availability for binding of SAP in vivo had no significant or consistent effect on the course or outcome of influenza infection, or on either viral replication or the anti-viral antibody response. Mouse SAP bound much less avidly than human SAP to influenza virus.

Conclusions: In marked contrast to the dramatic effects of SAP deficiency on host resistance to different bacterial infections, mouse SAP apparently plays no significant role during infection of mice with influenza virus. Human SAP binds much more avidly than mouse SAP to the virus, but also had no effect on any of the parameters measured and is therefore unlikely to be involved in human influenza infection.

\section{Introduction}

Serum amyloid P component (SAP), a normal plasma protein of the pentraxin family (1), binds specifically to amyloid fibrils, to certain anionic glycans, to DNA, chromatin and apoptotic cells, and to some bacteria (2). SAP bound to all these ligands acts as an anti-opsonin, protecting them from degradation in vitro and in vivo $(3,4)$. This contributes to pathogenesis of amyloidosis (5). In contrast, SAP has an important normal function in maintaining tolerance to DNA and chromatin, as SAP deficient mice spontaneously develop florid anti-nuclear autoimmunity (6). With respect to innate immunity against bacteria, SAP is protective in infection with organisms to which it does not bind, such as smooth

Address correspondence and reprint requests to: Mark B. Pepys, Centre for Amyloidosis and Acute Phase Proteins, Department of Medicine, Royal Free and University College Medical School, Rowland Hill Street, London NW3 2PF, UK. Phone: +44-20-7433 2801; fax: +44-20-7433 2803; e-mail: m.pepys@rfc.ucl.ac.uk.
Gram negative species $(4,7)$. However for organisms to which it does bind, such as $S$. pyogenes and rough strains of $E$. coli, SAP enhances virulence by protecting the bacteria against phagocytosis, and SAP deficient mice are much more resistant than wild type animals to these infections (4). Human SAP also binds to the influenza virus hemagglutinin and inhibits invasion of cells in vitro, whilst preincubation of the virus with human SAP in vitro or intra-nasal administration of human SAP to mice, have been reported to prevent infection in vivo $(8,9)$. These observations suggest that SAP might play a role in innate immunity to influenza infection. On the other hand the protective anti-opsonic effect of SAP binding with respect to bacteria, and the antiimmunogenic effect of SAP with respect to chromatin autoantigens suggested that SAP might rather contribute to influenza pathogenesis. We have therefore investigated the clinical course and immune response to mouse adapted strains of influenza virus in SAP deficient compared to wild type mice, as 
well as in human SAP transgenic animals, and mice treated with our novel SAP-inhibitory drug (7).

\section{Materials and Methods}

Viruses

Influenza virus strains A/Puerto Rico/8/34 (H1Nl) (PR8), A/Shanghai/24/90 (H3N2) (Shg/24) and A/Wilson Smith/33 (HINl) (WS/33) propagated in fertile hens' eggs, were from the stocks of the National Institute for Biological Standards and Control, UK, and from Roche Discovery Welwyn, UK.

\section{Mice and SAP}

All experiments were conducted in C57BL/6 mice, comparing wild type animals with SAP knockouts (5) and mice transgenic for human SAP (10). Both strains of genetically modified mice had been back crossed onto the C57BL/6 background for more than 10 generations. Human SAP was isolated and purified as previously described (11).

\section{Infection of Mice}

Mice were intra-nasally infected with influenza viruses $\left(20 \mu \mathrm{l}\right.$ per mouse containing $50 \mathrm{MID}_{50}$ or more in different experiments), while under light anesthesia (12). Nasal washes in PBSA were taken on days 3-7 after infection and samples were titrated for influenza virus on Madin-Darby Canine Kidney (MDCK) cells using standard procedures (13). Virus titers $\left(\mathrm{TCID}_{50} / \mathrm{ml}\right)$ were calculated by the Spearman Kärber method (14). In other experiments infected mice were weighed daily and their survival monitored, or groups were killed at the times shown for determination of anti-influenza virus antibody titers in serum and broncho-alveolar lavage fluid, and of virus titers in the lung. Following the last time point shown in the Figures reporting survival experiments, all remaining mice were vigorous and healthy with no signs of disease and were therefore culled 24 h later.

\section{Assay of Influenza Virus A/PR/8/34 from the Lungs of Infected Mice}

Lungs removed from A/PR/8/34 infected mice were homogenized for one minute at $20500 \mathrm{rpm}$ (Ultra Turrax T-25 homogenizer, IKA Labortechnik) in $1 \mathrm{ml}$ Eagles MEM medium, supplemented with $0.14 \%$ w/v BSA fraction V, $2 \mathrm{mM}$ L-glutamine, $100 \mathrm{U}$ penicillin/100 $\mu \mathrm{g}$ streptomycin. Homogenates were clarified by centrifugation at $2000 \mathrm{rpm}$ for $5 \mathrm{~min}$, and infectious influenza virus was titrated on MDCK cells as reported (15).

\section{Binding of SAP to Immobilized A/PR/8/34 Virus}

Microtiter plates (Costar high binding EIA/RIA strip plate, type 1, Corning, USA) were coated overnight at $4^{\circ} \mathrm{C}$ with $50 \mu \mathrm{l} /$ well of a highly purified $\mathrm{A} / \mathrm{PR} / 8 / 34$ preparation at $0.0125 \mathrm{mg} / \mathrm{ml}$ in $0.1 \mathrm{M}$
$\mathrm{Na}_{2} \mathrm{CO}_{3} / 0.1 \mathrm{M} \mathrm{NaHCO}, \mathrm{pH} 9.2$ (coupling buffer), and then washed three times with coupling buffer. Wells were blocked by incubation for $30 \mathrm{~min}$ at room temperature with $50 \mu \mathrm{l}$ coupling buffer containing $2 \% \mathrm{w} / \mathrm{v}$ BSA, followed by washing with coupling buffer alone and then preincubation with $10 \mathrm{mM}$ Tris, $140 \mathrm{mM} \mathrm{NaCl}, 2 \mathrm{mM} \mathrm{CaCl}$, $\mathrm{pH} 8.0$ (TC buffer) containing $4 \% \mathrm{w} / \mathrm{v}$ BSA and $0.05 \% \mathrm{v} / \mathrm{v}$ Tween 20 (TCBT buffer) for 2 min prior to assay. After removal of this equilibrating buffer, to each well were added TCBT buffer, TC, and ${ }^{125}$ I-human SAP (specific activity $3.1 \mathrm{MBq} / \mathrm{nmol}$ ) or ${ }^{125} \mathrm{I}$-mouse SAP (specific activity $3.7 \mathrm{MBq} / \mathrm{nmol}$ ) in $10 \mathrm{mM}$ Tris, $140 \mathrm{mM} \mathrm{NaCl}$, pH 8.0 (TN buffer), to provide 100,000 cpm per well in $50 \mu \mathrm{l}$ with final concentrations of $4 \% \mathrm{w} / \mathrm{v}$ BSA, $2 \mathrm{mM} \mathrm{CaCl}_{2}$ and $0.05 \% \mathrm{v} / \mathrm{v}$ Tween 20. Control wells contained the same reagents but with a final concentration of $10 \mathrm{mM}$ EDTA. The plates were then incubated at room temp for $2 \mathrm{~h}$ before washing each well three times with $200 \mu \mathrm{l}$ volumes of TCBT, or the same buffer in which the calcium was replaced with $10 \mathrm{mM}$ EDTA, as appropriate. Finally individual wells were counted after drying for $\mathrm{l} h$ at room temperature. Each determination was carried out in triplicate.

\section{Assay of Antibody to A/PR/8/34}

Wells coated with A/PR/8/34 virus as above were equilibrated for 2 min with $50 \mu$ l PBS containing $10 \mathrm{mM}$ EDTA, $1 \% \mathrm{w} / \mathrm{v}$ BSA, $0.2 \% \mathrm{v} / \mathrm{v}$ Tween 20 , $0.1 \% \mathrm{NaN}_{3}, \mathrm{pH} 7.4$ (PEBT buffer). Sera to be assayed were diluted appropriately in PEBT and $50 \mu \mathrm{l}$ volumes dispensed to wells in triplicate for incubation at $37^{\circ} \mathrm{C}$ for $1 \mathrm{~h}$ before washing three times with PEBT $(200 \mu \mathrm{l})$. Bound antibody was then detected using ${ }^{125}$ I-labeled sheep anti-whole mouse immunoglobulin antibody, $50,000 \mathrm{cpm}$ in $50 \mu \mathrm{l}$ of PEBT. After incubations at $37^{\circ} \mathrm{C}$ for $\mathrm{lh}$, wells were washed three times with PEBT $(200 \mu \mathrm{l})$, dried at room temperature for $\mathrm{l} \mathrm{h}$ and then counted. The assay was calibrated using dilutions of a single high titer mouse antiserum to which a value of 1000 antibody units was assigned.

\section{Results}

Influenza Virus Infection in Wild Type and SAP Deficient Mice

Wild type C57BL/6 mice mounted a vigorous acute phase response following intra-nasal infection with different strains of mouse adapted human influenza virus. Circulating SAP values rose from a baseline of 2-5 mg/l typical of this strain (16) to $20-30 \mathrm{mg} / \mathrm{l}$ on day 5 and $60-110 \mathrm{mg} / \mathrm{l}$ on days 7 and 10 . However, there was no consistent difference between normal wild type mice and SAP knockout mice, regardless of the severity of infection, with respect to the clinical course or outcome (Figs. 1 and 2), virus shedding in nasal washes (Table 1), virus titers in the lung (Table 2), or anti-viral antibody titers in the blood or bronchoalveolar lavage fluid (Table 2). 

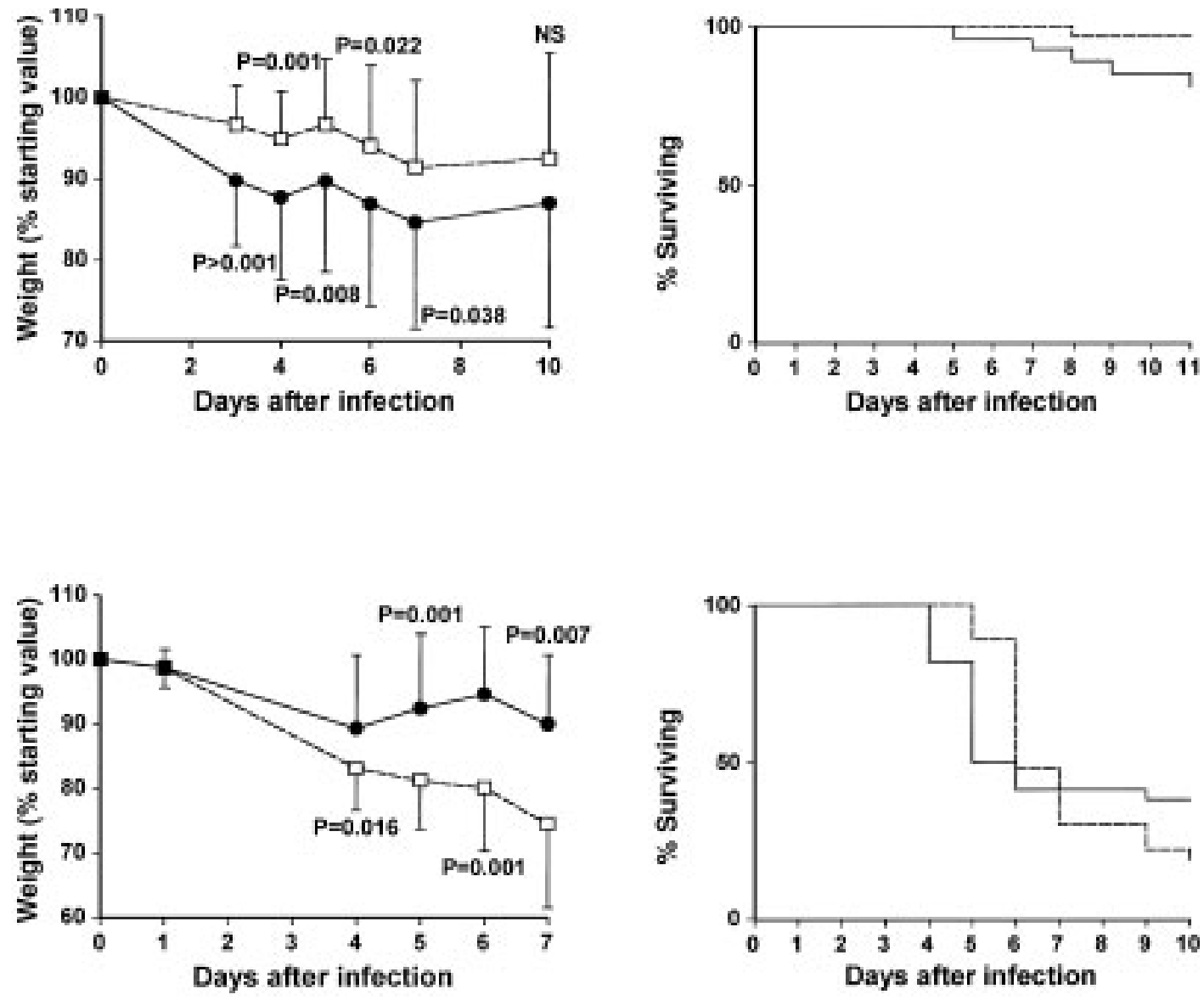

Fig. 1. Influenza infection in C57BL/6 wild type and SAP knockout mice. Upper panel, body weight (left) and survival (right) following intra-nasal infection on day 0 with the A/PR/8/34 viral strain, in 27 female wild type mice ( $\bullet$ and solid line) aged 15-16 weeks, mean (SD) initial body weight 24.0 (1.6) g, and 31 female SAP knockout mice ( $\square$ and broken line) aged 13-20 weeks, mean (SD) initial body weight 27.3 (1.8) g. Lower panel, body weight (left) and survival (right) following intranasal infection on day 0 with the A/WS/33 ATCC VR1520 viral strain, in 34 female wild type mice ( $\bullet$ and solid line) aged 10-13 weeks, mean (SD) initial body weight 20.5 (1.9) g, and 27 female SAP knockout mice ( $\square$ and broken line) aged 8-25 weeks, mean (SD) initial body weight 25.0 (2.7) g. Each point (left panels) represents the mean (SD) of all surviving animals in each group at each time point; significant differences between groups by t-test are shown by $\mathrm{P}$ values. In the milder infection (upper panel) the wild type mice showed greater percentage weight loss, but in the more severe infection (lower panel) the wild type animals showed less weight loss. In both experiments the SAP knockout mice had a wider age range, owing to their breeding pattern and the need to have substantial sized groups, and also had a greater mean initial weight. However there was no difference in survival between SAP knockout and wild type mice in either case, indicating that initial weight had no systematic effect on morbidity or outcome.

Influenza Virus Infection in SAP Deficient and Human SAP Transgenic Mice

Mouse SAP binds much less avidly to amyloid fibrils, and to other known SAP ligands, such as phosphoethanolamine $(11,17)$, than does human SAP (18). This was true also for binding of mouse and human SAP to immobilized influenza virus, by a factor of five or more (Fig. 3). However following intra-nasal infection with influenza virus, there was no difference between SAP knockout mice and SAP knockouts that were transgenic for human SAP, in either the clinical course or outcome (Fig. 4). The human SAP transgenics have a mean circulating concentration of human SAP of around $80 \mathrm{mg} / \mathrm{l}$, which is $2-3$ fold higher than the normal value in man (19), and thus provide a robust test for a significant role of SAP in influenza infection. Furthermore, the antibody responses to subcutaneous immunization with human clinical influenza virus vaccine was the same in human SAP transgenic mice on the wild type background, human SAP transgenic mice on the mouse SAP knockout background, and SAP knockout mice (results not shown).

\section{Effect of Passive Administration of Human SAP, and Inhibition of SAP Binding In Vivo on Influenza Infection}

Reconstitution of SAP knockout mice with a very large dose of pure human SAP, $5 \mathrm{mg}$ given by intraperitoneal injection just before intra-nasal infection with influenza virus and again after $24 \mathrm{~h}$, had no 


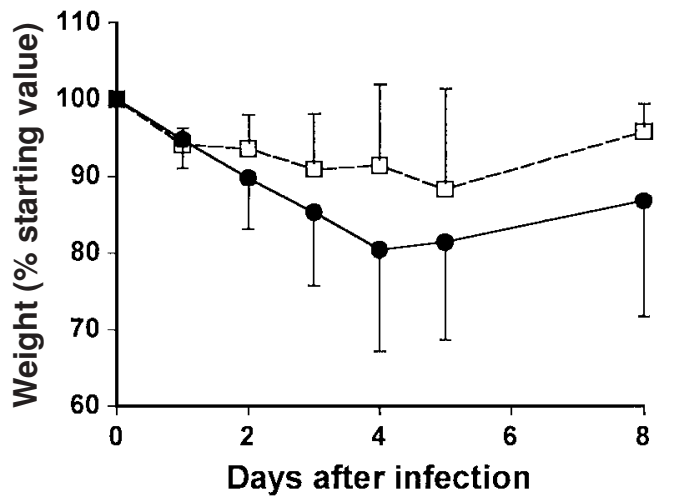

Fig. 2. Influenza infection in C57BL/6 wild type and SAP knockout mice. Body weight following intra-nasal infection on day 0 with the A/PR/8/34 viral strain in 12 female wild type mice (๑), aged 9-11 weeks, mean (SD) initial body weight $21.0(2.0) \mathrm{g}$, and 12 female SAP knockout mice $(\square)$ aged 9-11 weeks, mean (SD) initial body weight 23.0 (1.8) g. Four mice from each group were killed on days 3, 5 and 8 for measurement of antibody response and viral titers, as shown in Table 2. Each point represents the mean (SD) of all surviving animals in each group at each time point, and there was no significant difference between the groups.

effect on outcome. At day 10 there were 9 survivors out of 29 mice in the control group of SAP knockouts treated with buffer alone, and 13 survivors out of 29 in the group receiving human SAP. The plasma half life of human SAP in mice is about $3 \mathrm{~h} \mathrm{(20)}$ and control uninfected mice receiving these huge amounts of human SAP had very high circulating concentrations that still exceeded the normal human plasma SAP value $(2 \mathrm{l})$ of about $30 \mathrm{mg} / \mathrm{l}$ at $48 \mathrm{~h}$. Availability in the body of abundant human SAP during the first days thus had no effect on the course of influenza virus infection.

Our potent inhibitor of SAP binding, (R)-1[6-[(R)-2-Carboxy-pyrrolidin-1-yl]-6-oxo-hexanoyl] pyrrolidine-2-carboxylic acid (22), completely abrogated the inhibition by human SAP of influenza virus induced hemagglutination in vitro, and had an IC50 of $\sim 2 \mu \mathrm{M}$ for inhibition of binding of radiolabelled human SAP to immobilized A/PR/8/34 virus. However, treatment of wild type mice with the drug had no effect on morbidity or outcome following influenza virus infection (results not shown). This contrasts sharply with the action of the drug in significantly ameliorating the course of lethal infection of mice with bacteria to which SAP binds (4), and thus provides a robust test for a possible role of endogenous mouse SAP in influenza infection.

\section{Discussion}

The observation that SAP binds to the influenza virus, inhibits hemagglutination and invasion of

Table 1. Influenza virus shedding during sub-lethal infection in wild type C57BL/6 and SAP knockout mice

\begin{tabular}{|c|c|c|c|c|c|c|}
\hline \multirow[b]{2}{*}{ Mouse no. } & \multicolumn{6}{|c|}{ Virus Titer in Nasal Washings (TC $\left.\left(\mathrm{ID}_{50} / \mathrm{ml}\right)\right)$} \\
\hline & Day 3 & Day 4 & Day 5 & Day 6 & Day 7 & Mean \\
\hline \multicolumn{7}{|c|}{ Gp 1 SAP knockouts } \\
\hline 1 & 4.3 & ND & ND & ND & ND & \\
\hline 2 & 3.5 & ND & ND & ND & ND & \\
\hline 3 & 3.7 & 3.4 & 2.2 & 2.0 & 0.5 & 2.36 \\
\hline 4 & 3.6 & 1.6 & 1.0 & 3.0 & 1.8 & 2.20 \\
\hline 5 & 3.0 & 2.6 & 0.5 & 2.8 & 0.5 & 1.88 \\
\hline 6 & 4.4 & 2.8 & 1.9 & 1.1 & 1.9 & 2.42 \\
\hline 7 & 3.7 & 1.7 & 3.6 & 2.2 & 0.5 & 2.34 \\
\hline Mean & 3.74 & 2.42 & 1.84 & 2.22 & 1.04 & 2.24 \\
\hline \multicolumn{7}{|c|}{ Gp 2 C57BL/6 wild type } \\
\hline 1 & 2.2 & 2.9 & 2.8 & 1.9 & 1.8 & 2.32 \\
\hline 2 & 2.8 & 1.5 & 2.8 & 2.2 & 2.7 & 2.40 \\
\hline 3 & 3.5 & 2.8 & 0.5 & 2.7 & 0.5 & 2.00 \\
\hline 4 & 2.3 & 3.0 & 2.0 & 2.7 & 1.7 & 2.34 \\
\hline 5 & 2.8 & 2.1 & 2.5 & 1.3 & 2.6 & 2.26 \\
\hline 6 & 3.7 & 2.8 & 3.0 & 1.2 & 0.5 & 2.24 \\
\hline 7 & 3.4 & 2.6 & 2.6 & 1.2 & 1.7 & 2.30 \\
\hline 8 & 3.4 & 3.3 & 2.0 & 1.7 & 1.6 & 2.40 \\
\hline 9 & 2.2 & 2.7 & 1.8 & 1.6 & 1.6 & 1.98 \\
\hline 10 & 2.1 & 1.7 & 2.9 & 1.8 & 2.3 & 2.24 \\
\hline Mean & 2.84 & 2.54 & 2.29 & 1.83 & 1.7 & 2.25 \\
\hline
\end{tabular}

Mice were infected intra-nasally on day 0 with the A/Shanghai/24/90 strain of influenza virus. Virus shedding was measured by titration of nasal washings taken daily as shown. 
Table 2. Antibody response and viral titers during influenza virus infection in C57BL/6 wild type and SAP knockout mice

\begin{tabular}{|c|c|c|c|c|c|c|}
\hline \multirow[b]{2}{*}{ Day } & \multicolumn{2}{|c|}{$\begin{array}{l}\text { Serum Antibody } \\
{[\text { Mean (SD)] }}\end{array}$} & \multicolumn{2}{|c|}{$\begin{array}{l}\text { BAL Antibody } \\
\text { [Mean (SD)] }\end{array}$} & \multicolumn{2}{|c|}{$\begin{array}{c}\text { Lung Viral Titer } \\
\text { [TCID }_{50}, \text { Individual Values] }\end{array}$} \\
\hline & Wild Type & SAP ko & Wild Type & SAP ko & Wild Type & SAP ko \\
\hline 3 & $59(8)$ & $94(30)$ & $25(7)$ & $17(8)$ & $3.75,4.75,4.75, \mathrm{NA}$ & $<0.75,<0.75,2.5,3.5$ \\
\hline 5 & $485(194)$ & $311(138)$ & $13(4)$ & $17(9)$ & $3.75,3.75,4.5,4.5$ & $3.5,4.5,4.75,5.0$ \\
\hline 8 & 4016 (777) & $4350(254)$ & $300(155)$ & $58(21)$ & $1.25,1.25,1.5,4.0$ & $1.0,1.5,1.75,2.75$ \\
\hline
\end{tabular}

Mice were infected intra-nasally on day 0 with the A/PR/8/34 strain of influenza virus, and batches of 4 animals were killed on days 3,5 and 8 to provide serum and bronchoalveolar fluid for anti-influenza virus antibody titration, and whole lung homogenates for virus titration. Total mouse anti-influenza virus antibody was estimated by solid phase immunoradiometric assay calibrated with a single standard high titer mouse antiserum to which a value of 1000 antibody units was assigned. There were no spontaneous deaths and the weights of all surviving animals on each day are shown in Fig. 2.

cells in vitro, suggested that SAP might contribute to innate defenses against this important pathogen (8). Preincubation of influenza virus with human SAP, and intra-nasal administration of human SAP, also apparently reduced the virulence of influenza infection in mice (9). On the other hand our findings in SAP deficient mice, in relation to bacterial infection (4) and in relation to anti-nuclear autoimmunity (6), raised the possibility that binding of SAP under physiological conditions in vivo may contribute to virulence of the influenza virus by reducing phagocytosis of the virus, and possibly also its immunogenicity. This was of particular interest in view of our recent development of a potent, non-toxic, low molecular weight compound that selectively blocks binding of SAP to its ligands in vivo (7). However the present extensive series of experiments showed no consistent significant effects of the presence, absence or availability of mouse or human SAP on

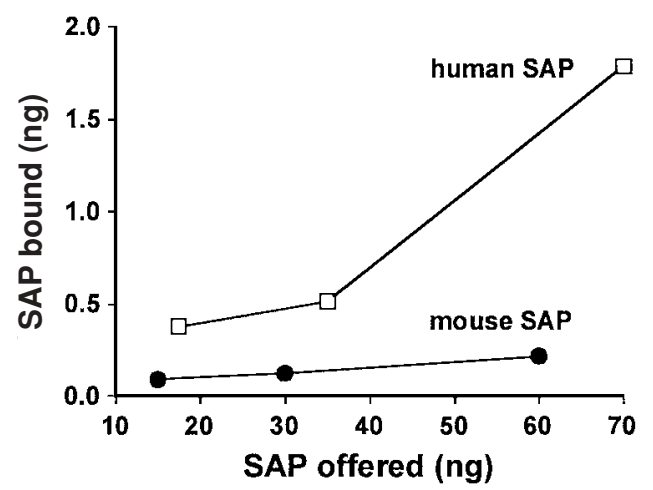

Fig. 3. Calcium-dependent binding of ${ }^{125}$ I-labeled mouse and ${ }^{125}$ I-labeled human SAP to immobilized A/PR/8/34 influenza virus. Each point is the mean of triplicate measurements. There was no detectable binding of SAP in the presence of EDTA. morbidity, outcome, viral replication or antibody responses following intra-nasal infection of mice with mouse adapted influenza virus, using three different virus strains, and regardless of the infecting dose.

The pentraxin family of plasma proteins, including SAP, have been very stably conserved in evolution (23-26), suggesting that they have important biological functions. SAP is the single normal plasma protein that specifically undergoes calcium-dependent binding to DNA and chromatin $(27,28)$, and SAP binds specifically to apoptotic cells both in vitro and in vivo (29). Binding of SAP stabilizes chromatin, retarding its degradation in vitro and in vivo, and the functional importance of these effects is reflected by the spontaneous development of marked anti-nuclear autoimmunity in SAP deficient mice (6). Furthermore immunization with extrinsic chromatin induces greater antibody responses in SAP knockout mice than in wild type animals (6). In addition to its binding to chromatin, SAP also binds to some bacteria (30) and inhibits their subsequent phagocytosis and destruction by neutrophils, both in vitro and in vivo (4). This is reflected in the markedly enhanced resistance of SAP deficient mice to otherwise lethal infection with such organisms (4). Passive administration of human SAP to SAP knockout mice reconstitutes wild type susceptibility, whilst (R)1-[6-[(R)-2-Carboxy-pyrrolidin-1-yl]-6-oxo-hexnoyl] pyrrolidine-2-carboxylic acid, the drug that inhibits SAP binding, confers enhanced resistance on wild type animals (4). In contrast, SAP knockouts are more susceptible than wild type mice during infection with bacteria to which SAP does not bind, indicating that SAP also has host defense functions $(4,7)$. For example, SAP may protect against toxic products of microbial and/or host origin released during infection. 

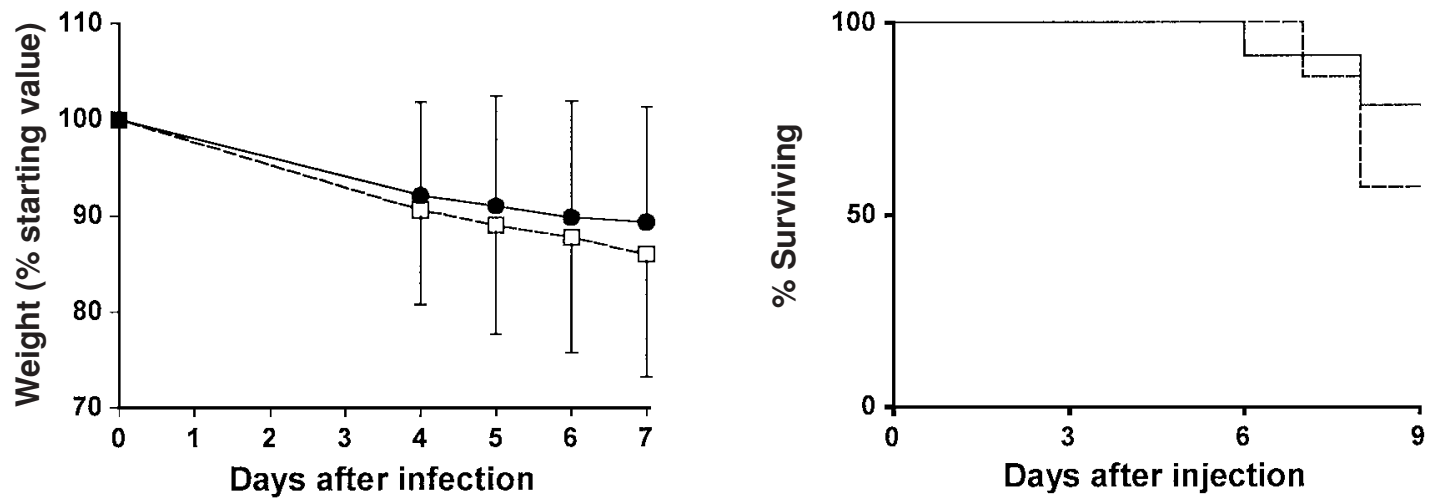

Fig. 4. Influenza infection in C57BL/6 SAP knockout mice and C57BL/6 SAP knockouts transgenic for human SAP. Body weight (left) and survival (right) following intra-nasal infection on day 0 with the A/PR/8/34 viral strain, in 23 female human SAP transgenic mice ( $\bigcirc$ and solid line) aged 17-39 weeks, mean (SD) 29.0 (8.7) weeks, mean (SD) initial body weight 31.9 (3.7) g, and 23 female SAP knockout mice ( $\square$ and broken line) aged 17-39 weeks, mean (SD) 31.0 (6.3) weeks, mean (SD) initial body weight 30.6 (3.2) g. Each point (left) represents the mean (SD) of all surviving animals in each group at each time point. There was no significant difference in weight loss or survival between the groups.

However, despite binding of SAP to influenza virus particles (8), availability of SAP in vivo had no apparent effect on influenza infection or the host response to this virus. Mice without SAP handled the infection normally and SAP is thus not a necessary component of host defense against influenza virus in this species. We show here that mouse SAP binds only weakly to influenza virus, but even human SAP, which binds more avidly, had no effect either in increasing resistance to infection or in promoting viral virulence, despite being expressed at high levels in transgenic mice or administered parenterally in high doses. It remains possible that, in contrast to the situation with respect to pyogenic bacteria (4), human SAP may have no biological action on influenza virus infection in mice because it may not be recognized by necessary molecular or cellular components of murine host defence mechanisms. However, unlike the reported effects of SAP in vitro (8) or following intra-nasal administration (9), it is clear that in mice the systemic presence of either human or mouse SAP has no significant influence on the replication or effects of influenza virus, or the host response in vivo. This is likely to be true also in man and the inhibitor of SAP binding, (R)-1-[6-[(R)-2-Carboxy-pyrrolidin-1-yl]6-oxo-hexanoyl]pyrrolidine-2-carboxylic acid, thus probably will not have a role in treatment of influenza virus infection.

\section{Acknowledgments}

This work was supported in part by Medical Research Council (U.K.) Programme Grant G97900510 to M.B. Pepys. We thank Dr. John Wood and Dr. Diane Major for providing mouse adapted influenza virus and for invaluable scientific and technical assistance. We thank Mrs. Beth Jones for expert preparation of the manuscript.

\section{References}

1. Pepys MB, Baltz ML. (1983) Acute phase proteins with special reference to $\mathrm{C}$-reactive protein and related proteins (pentaxins) and serum amyloid A protein. Adv. Immunol. 34: 141-212.

2. Pepys MB, Booth DR, Hutchinson WL, et al. (1997) Amyloid P component. A critical review. Amyloid: Int. J. Exp. Clin. Invest. 4: 274-295.

3. Tennent GA, Lovat LB, Pepys MB. (1995) Serum amyloid P component prevents proteolysis of the amyloid fibrils of Alzheimer's disease and systemic amyloidosis. Proc. Natl. Acad. Sci. USA 92: 4299-4303.

4. Noursadeghi M, Bickerstaff MCM, Gallimore JR, et al. (2000) Role of serum amyloid P component in bacterial infection: protection of the host or protection of the pathogen. Proc. Natl. Acad. Sci. USA 97: 14584-14589.

5. Botto M, Hawkins PN, Bickerstaff MCM, et al. (1997) Amyloid deposition is delayed in mice with targeted deletion of the serum amyloid P component gene. Nature Med. 3: 855-859.

6. Bickerstaff MCM, Botto M, Hutchinson WL, et al. (1999) Serum amyloid $\mathrm{P}$ component controls chromatin degradation and prevents antinuclear autoimmunity. Nature Med. 5: 694-697.

7. Pepys MB. (1999) The Lumleian Lecture. C-reactive protein and amyloidosis: from proteins to drugs? In: G. Williams, ed. Horizons in Medicine, Vol. 10. London: Royal College of Physicians, pp. 397-414.

8. Andersen O, Vilsgaard Ravn K, Sørensen IJ, et al. (1997) Serum amyloid P component binds to influenza A virus haemagglutinin and inhibits the virus infection in vitro. Scand. J. Immunol. 46: 331-337.

9. Horváth A, Andersen I, Junker K, et al. (2001) Serum amyloid $P$ component inhibits influenza A virus infections: in vitro and in vivo studies. Antiviral Res. 52: 43-53.

10. Tashiro F, Yi S, Wakasugi S, et al. (1991) Role of serum amyloid $\mathrm{P}$ component for systemic amyloidosis in transgenic mice carrying human mutant transthyretin gene. Gerontology 37 (Suppl. 1): 56-62.

11. Hawkins PN, Tennent GA, Woo P, Pepys MB. (1991) Studies in vivo and in vitro of serum amyloid $P$ component in normals and in a patient with AA amyloidosis. Clin. Exp. Immunol. 84: $308-316$.

12. Wood JM, Coombes AGA, Major D, et al. (1996) Polylactide microparticles as adjuvants for parenteral delivery of influenza virus vaccines. In: L.E. Brown, A.W. Hampson, R.G. Webster, eds. Options for the control of influenza. III, Elsevier Science BV, pp. 810-814. 
13. Oxford JS, Corcoran T, Knott R, et al. (1987) Serological studies with influenza $\mathrm{A}(\mathrm{H} 1 \mathrm{Nl})$ viruses cultivated in eggs or in a canine kidney cell line (MDCK). Bull. World Health Organ. 65: 181-187.

14. Finney DJ. (1952) Statistical method in biological assay. In: Charles Griffin, London, pp. 524-530.

15. Hayden FG, Rollins BS, Madren LK. (1994) Anti-influenza virus activity of the neuraminidase inhibitor 4-guanidinoNeu5Ac2en in cell culture and in human respiratory epithelium. Antiviral Res. 25: 123-131.

16. Pepys MB, Baltz M, Gomer K, et al. (1979) Serum amyloid $\mathrm{P}$-component is an acute-phase reactant in the mouse. Nature 278: 259-261.

17. Pontet M, Engler R, Jayle MF. (1978) One step preparation of both human C-reactive protein and Clt. Fed. Eur. Biol. Soc. Lett. 88: $172-178$.

18. Hawkins PN, Myers MJ, Epenetos AA, et al. (1988) Specific localization and imaging of amyloid deposits in vivo using ${ }^{123}$ I-labeled serum amyloid P component. J. Exp. Med. 167: 903-913.

19. Nelson SR, Tennent GA, Sethi D, et al. (1991) Serum amyloid $\mathrm{P}$ component in chronic renal failure and dialysis. Clin. Chim. Acta 200: 191-200.

20. Hutchinson WL, Noble GE, Hawkins PN, Pepys MB. (1994) The pentraxins, C-reactive protein and serum amyloid P component, are cleared and catabolized by hepatocytes in vivo. J. Clin. Invest. 94: 1390-1396.

21. Nelson SR, Tennent GA, Sethi D, et al. (1991) Serum amyloid $\mathrm{P}$ component in chronic renal failure and dialysis. Clin. Chim. Acta 200: 191-200.
22. Hertel C, Norcross RD, Jakob-Roetne R, Hoffmann, T. (2001) Patent No. US6262089: D-proline derivatives (Hoffmann La Roche).

23. Pepys MB, Dash AC, Fletcher TC, et al. (1978) Analogues in other mammals and in fish of human plasma proteins C-reactive protein and amyloid P component. Nature 273: $168-170$.

24. Baltz ML, de Beer FC, Feinstein A, et al. (1982) Phylogenetic aspects of C-reactive protein and related proteins. Ann. N.Y. Acad. Sci. 389: 49-75.

25. Tennent GA, Butler PJG, Hutton T, et al. (1993) Molecular characterization of Limulus polyphemus C-reactive protein. I. Subunit composition. Eur. J. Biochem. 214: 91-97.

26. Srinivasan N, Rufino SD, Pepys MB, et al. (1996) A superfamily of proteins with the lectin fold. Chemtracts-Biochem. Mol. Biol. 6: 149-164.

27. Pepys MB, Butler PJG. (1987) Serum amyloid P component is the major calcium-dependent specific DNA binding protein of the serum. Biochem. Biophys. Res. Commun. 148: 308-313.

28. Butler PJG, Tennent GA, Pepys MB. (1990) Pentraxinchromatin interactions: serum amyloid $\mathrm{P}$ component specifically displaces Hl-type histones and solubilizes native long chromatin. J. Exp. Med. 172: 13-18.

29. Hintner H, Booker J, Ashworth J, et al. (1988) Amyloid P component binds to keratin bodies in human skin and to isolated keratin filament aggregates in vitro. J. Invest. Dermatol. 91: 22-28.

30. Hind CRK, Collins PM, Baltz ML, Pepys MB. (1985) Human serum amyloid $\mathrm{P}$ component, a circulating lectin with specificity for the cyclic 4,6-pyruvate acetal of galactose. Interactions with various bacteria. Biochem. J. 225: 107-111. 